\title{
Preclinical Pharmacokinetics of MI-219, a Novel Human Double Minute 2 (HDM2) Inhibitor and Prediction of Human Pharmacokinetics
}

\author{
Peng Zou ${ }^{1}$, Nan Zheng ${ }^{1}$, Yanke $\mathrm{Yu}^{1}$, Shanghai $\mathrm{Yu}^{2}$, Wei Sun${ }^{2}$, Donna McEachern ${ }^{2}$, Yongsheng Yang ${ }^{3}$, Lawrence X. Yu \\ Shaomeng Wang ${ }^{2 *}$, Duxin Sun $^{1}$ \\ ${ }^{1}$ Department of Pharmaceutical Sciences, ${ }^{2}$ Departments of Internal Medicine and Medicinal Chemistry and Comprehensive \\ Cancer Center, University of Michigan, Ann Arbor, MI; ${ }^{3}$ Office of Testing and Research and ${ }^{4}$ Office of Generic Drugs, \\ Food and Drug Administration, Rockville, MD.
}

Received, January 30, 2012; Revised, April 1, 2012; Accepted, April 5, 2012; Published, April 7, 2012.

\begin{abstract}
Purpose. The two purposes of this study were evaluating preclinical pharmacokinetics of MI219 and predicting clearance $(\mathrm{CL})$ and volume of distribution at steady-state $\left(\mathrm{Vd}_{\mathrm{ss}}\right)$ of $\mathrm{MI}-219$ in humans. Methods. Pharmacokinetic studies were conducted on mice, rats, dogs, and monkeys. Human CL of MI-219 was predicted using allometric scaling (SA), multi-exponential allometric scaling (ME), rule of exponents (RoE), single species scaling, two-term power equation (TTPE), physiologically based in vitro-in vivo extrapolation (IVIVE), and $\mathrm{f}_{\mathrm{u}}$ corrected intercept method (FCIM). In vitro assays were conducted to determine in vitro intrinsic CL, protein binding, and blood-plasma partition coefficients. To estimate half-life of MI-219, plasma concentration-time profile in humans was predicted using kallynochron and apolysichron time transformation (Dedrick plots) and normalization with $\mathrm{MRT}$ and $\mathrm{Vd}_{\mathrm{ss}}$ (Wajima's method). In addition, simultaneous interspecies scaling of $\mathrm{CL}, \mathrm{Vd}_{\mathrm{ss}}$ and concentration-time profile were performed by using Nonlinear Mixed Effects Modeling (NONMEM). Results. Preclinical studies showed that the elimination of MI-219 was mainly through metabolism. The validation using observed monkey CL and $\mathrm{Vd}_{\mathrm{ss}}$ showed that MA, IVIVE and Oie-Tozer methods were accurately than the other methods. Human CL of MI-219 predicted by ME and IVIVE was between $0.237-0.342 \mathrm{~L}^{*} \mathrm{~h}^{-1} * \mathrm{~kg}^{-1}$. Human $\mathrm{Vd}_{\mathrm{ss}}$ predicted by Oie-Tozer method and allometric scaling of unbound volume of distribution of tissues $\left(\mathrm{V}_{\mathrm{T}} / \mathrm{fu}_{\mathrm{T}}\right)$ method was between $0.93-1.40 \mathrm{~L} * \mathrm{~kg}^{-1}$. Superimposition of rat, monkey and dog data was observed in Dedrick plots and Wajima's transformations. Conclusions. The predicted human pharmacokinetics is useful for the design of first-in-human study.
\end{abstract}

This article is open to POST-PUBLICATION REVIEW. Registered readers (see "For Readers") may comment by clicking on ABSTRACT on the issue's contents page.

\section{INTRODUCTION}

MI-219 is a potent, highly selective and orally active small-molecule inhibitor of human double minute 2 (HDM2)-p53 interaction (Figure $S 1$ ) (13). MI-219 stimulates rapid but transient p53 activation in tumor tissues, resulting in inhibition of cell proliferation, selective induction of cancer cell apoptosis, and complete tumor growth inhibition in xenograft models. Preclinical studies have shown that MI-219 is a promising lead candidate for p53 wild-type cancer therapy.

Prediction of human pharmacokinetics is an essential element in clinical development of a potential drug molecule. Over the past few decades, numerous empirical or physiological approaches have been developed for quantitative predictions of human clearance $(\mathrm{CL})(4,5)$, volume of distribution at steady-state $\left(\mathrm{Vd}_{\mathrm{ss}}\right)(6,7)$ and human plasma concentration-time profile from preclinical animal data $(8,9)$. These predictive approaches typically use in vivo preclinical animal data and/or in vitro metabolism and disposition data obtained from human tissue such as microsomes or hepatocytes. However, there is not a standard method superior to other methods for each individual compound.

\footnotetext{
Correspondence Author: Duxin Sun, PhD; Department of Pharmaceutical Sciences College of Pharmacy; The University of Michigan; 428 Church Street, Ann Arbor, MI, USA; Email: duxins@umich.edu.

Shaomeng Wang, PhD; Departments of Internal Medicine and Medicinal Chemistry and Comprehen-sive Cancer Center, University of Michigan; 1500 E. Medical Center Dr.; Ann Arbor, MI 48109 USA;

Email: shaomeng@umich.edu
} 
Each approach has its unique advantages and disadvantages in its application to predicting human pharmacokinetics (5).

In current study, we first delineated in vitro and in vivo pharmacokinetics of MI-219 in mice, rats, dogs and monkeys and quantitatively predicted pharmacokinetics of MI-219 in humans. Preclinical studies showed that the elimination of MI-219 was mainly due to drug metabolism. Various methods were utilized to predict $\mathrm{CL}$ and $\mathrm{Vd}_{\mathrm{ss}}$ values of MI219 in human. The plasma concentration-time profile in humans was also predicted using Dedrick plots and Wajima's method (9-12).

\section{METHODS}

\section{Reagents}

MI-219 and MI-343 (internal standard) were synthesized using a previously published method $(2,13)$. Mouse, rat, dog, monkey and human liver microsomes were supplied by Sigma (St. Louis, MO, USA) or Xenotech (Lenexa, KS, USA). All other chemicals and reagents were purchased from commercial suppliers and were of HPLC grade.

\section{Metabolic stability assay}

The metabolic stability of MI-219 was assessed in human (a pool of fifty subjects), CD-1 mouse (a pool of ten male mice), Sprague-Dawley rat (a pool of fifteen male rats), beagle dog (a pool of eight male dogs), and cynomolgous monkey (a pool of six male monkeys) liver microsomes. The enzymes were activated by $\beta$-NADPH (reduced form). The incubation solution was diluted with $0.1 \mathrm{M}$ phosphate buffer (containing $\mathrm{MgCl}_{2}$ ) to $0.4 \mathrm{~mL}$. The final concentrations of MI-219, liver microsomes, $\beta$-NADPH, and $\mathrm{MgCl}_{2}$ were $1 \mu \mathrm{M}, 1$ $\mathrm{mg} / \mathrm{mL}, 1 \mathrm{mM}$, and $3.3 \mathrm{mM}$ respectively. The solution was incubated at $37^{\circ} \mathrm{C}$. An aliquot of $40 \mu \mathrm{l}$ of mixture was collected at $0,5,10,15,30,45$ and $60 \mathrm{~min}$, and then proteins were precipitated with $120 \mu \mathrm{l}$ of ice-cold acetonitrile containing an internal standard $(100 \mathrm{ng} / \mathrm{mL})$. The samples were centrifuged at $21913 \mathrm{~g} \times 5 \mathrm{~min}$ and $10 \mu \mathrm{l}$ of supernatant was injected into LC-MS/MS. All incubations were performed in triplicate.

An Agilent 1200 HPLC system coupled with a Qtrap 3200 mass spectrometer (Applied Biosystems, MDS Sciex Toronto, Canada) was used to quantify the remaining MI-219 in the liver microsome samples. The processed samples were injected on a Zorbax Bonus-RP column $(2.1 \mathrm{~mm} \times 50 \mathrm{~mm}, 5 \mu \mathrm{m})$. The system was run in isocratic mode with mobile phase consisting of methanol and water in the ratio of $85: 15(\mathrm{v} / \mathrm{v})$ at a flow rate of $0.3 \mathrm{~mL} / \mathrm{min}$. An electrospray ion source in the negative-ion multiple reaction monitoring (MRM) mode was used for detection. The MRM transition channel was $\mathrm{m} / \mathrm{z} 550$ to $\mathrm{m} / \mathrm{z} 306$ for MI219 and $\mathrm{m} / z 596$ to $\mathrm{m} / z 352$ for IS. The ion spray voltage was set at $-2700 \mathrm{~V}$. Ionization temperature was set as $700{ }^{\circ} \mathrm{C}$. Data acquisition and quantitation were performed using analyst software version 1.4.1 (Applied Biosystems, MDS Sciex Toronto, Canada). The peak area ratios (MI-219 peak area/ internal standard peak area) were plotted against time and the data were fitted with a two compartment model using WinNonlin version 3.2 (Pharsight Corporation, Mountain View, CA, USA) to calculate the initial elimination rate constants $\left(\mathrm{K}_{\mathrm{e}}\right)$.

\section{Animals}

The animal procedures were performed according to a protocol approved by the University Committee for the Use and Care of Animals (UCUCA) at the University of Michigan. Male CD-1 (ICR) mice ( $\mathrm{n}=33$, body weight $18 \pm 1.7 \mathrm{~g}$ ), male Sprague Dawley rats $(n=3$, body weight $195 \pm 15 \mathrm{~g})$, male cynomolgus monkeys $(\mathrm{n}=6$, body weight $2.5 \pm 0.26$ $\mathrm{kg})$, and male beagle dogs $(\mathrm{n}=3$, bodyweight $8.0 \pm$ $1.1 \mathrm{~kg}$ ) were used for pharmacokinetic studies. Animals were maintained under a 12-h light/ dark cycle in cages with free access to commercial food pellets. Water was supplied ad libitum. All blood samples were collected into heparinized polypropylene microcentrifuge tubes.

\section{Mouse pharmacokinetic study}

Thirty three male CD-1 mice were given an intravenous dose of $10 \mathrm{mg} / \mathrm{kg}$ of MI-219 dissolved in saline containing $20 \%$ polyethylene glycol (PEG 400 ) and 3\% cremophor via the tail vein (MI-219 concentration $2 \mathrm{mg} / \mathrm{mL}$ and injection volume 5 $\mathrm{mL} / \mathrm{kg}$ ). Approximately $0.2 \mathrm{~mL}$ of blood was collected from each mouse by terminal cardiac puncture under isoflurane. Blood samples $(n=3$ mice per time point) were taken from intravenously dosed mice at the following time points: before dosing and subsequently at 5, 15, 30, $45 \mathrm{~min}, 1,2$, $3,5,9$, and $24 \mathrm{~h}$ after i.v administration. Blood samples were centrifuged at $1370 \mathrm{~g}$ for $10 \mathrm{~min}$ within $30 \mathrm{~min}$ of collection and plasma was harvested. Plasma samples were stored at $-70^{\circ} \mathrm{C}$ until analysis. 
Rat pharmacokinetic study

Two days before the initiation of the study, Sprague-Dawley rats were carotid cannulated using anaesthesia consisting of intraperitoneal administration of ketamine $(100 \mathrm{mg} / \mathrm{kg})$ and xylazine $(10 \mathrm{mg} / \mathrm{kg})$. Three male Sprague-Dawley rats were given an intravenous dose of $5 \mathrm{mg} / \mathrm{kg}$ of MI-219 in 10\% DMSO and 90\% saline (MI-219 concentration $5 \mathrm{mg} / \mathrm{mL}$ and injection volume 1 $\mathrm{mL} / \mathrm{kg}$ ) via a tail vein. Blood samples (approximately $0.2 \mathrm{~mL}$ per sample) were collected from each animal via a jugular vein catheter at predose and 5, 15, $30 \mathrm{~min}, 1,2,4,6,8$, and 24 hours post-dose. Blood samples were centrifuged within 30 min of collection and plasma was harvested. Plasma samples were stored at approximately $-70^{\circ} \mathrm{C}$ until analysis.

\section{Monkey pharmacokinetic study}

Six male cynomolgus monkeys were given 10 $\mathrm{mg} / \mathrm{kg}$ of MI-219 in 10\% DMSO and $90 \%$ saline (MI-219 concentration $10 \mathrm{mg} / \mathrm{mL}$ and injection volume $1 \mathrm{~mL} / \mathrm{kg}$ ) via a saphenous vein. Blood samples (approximately $1 \mathrm{~mL}$ per sample) were collected from the femoral vein of each animal at pre-dose, 5, 15, 30, $60 \mathrm{~min}$, and 1.5, 2, 3, 4, 6, 8, and $24 \mathrm{~h}$ post-dose. All blood samples were collected into heparinized polypropylene microcentrifuge tubes. Blood samples were centrifuged within $1 \mathrm{~h}$ of collection and plasma was harvested and stored at approximately $-70^{\circ} \mathrm{C}$ until analysis.

\section{Dog pharmacokinetic study}

Three male beagle dogs were given a single intravenous dose of $2 \mathrm{mg} / \mathrm{kg}$ of MI-219 in $10 \%$ DMSO and $90 \%$ saline (MI-219 concentration 2 $\mathrm{mg} / \mathrm{mL}$ and injection volume $1 \mathrm{~mL} / \mathrm{kg}$ ) via a cephalic vein. Blood samples (approximately $2 \mathrm{~mL}$ per sample) were collected from the jugular vein of animals at pre-dose, 7, 12 and 30 min post-dose; and 1, 3, 4, 6, 8, 12 and $24 \mathrm{~h}$ post-dose. All blood samples were collected in tubes containing heparin. Blood samples were centrifuged and plasma was harvested within $1 \mathrm{~h}$ of collection. Plasma samples were stored at approximately $-70^{\circ} \mathrm{C}$ until analysis.

\section{Plasma sample preparation and LC-MS/MS analysis}

To prepare the plasma sample for LC-MS/MS analysis, ice-cold acetonitrile containing $100 \mathrm{ng} / \mathrm{mL}$ internal standard (MI-343) was added to $50 \mu \mathrm{l}$ mouse plasma samples or $100 \mu 1$ of plasma samples of rats, monkeys or dogs to precipitate proteins. After centrifugation at 13,000 rpm for $5 \mathrm{~min}, 10 \mu \mathrm{L}$ of the supernatant was introduced into the LCMS/MS system. LC-MS/MS conditions are similar to that used for microsomal sample analysis. The lower limits of quantitation (LOQs) in plasma are $2.1 \pm 11 \% \mathrm{ng} / \mathrm{mL}$ (mouse), $1.0 \mathrm{ng} / \mathrm{mL} \pm 13 \%$ (rat), $1.0 \mathrm{ng} / \mathrm{mL} \pm 9 \%$ (monkey), and $1.5 \mathrm{ng} / \mathrm{mL} \pm 10 \%$ (dog).

\section{Pharmacokinetic analysis}

All pharmacokinetic parameters were calculated by noncompartmental methods using WinNonlin version 3.2 (Pharsight Corporation, Mountain View, CA, USA). Parameters are presented as a mean \pm standard deviation (SD).

Plasma and liver microsome protein binding.

Plasma protein binding was measured using a previously published method (14). Plasma was spiked with MI-219 to yield a final concentration of $5 \mu \mathrm{M}$. After incubation at $37^{\circ} \mathrm{C}$ for $1 \mathrm{~h}$, an aliquot was transferred to a $10 \mathrm{kD}$ cut-off ultrafiltration device (Millipore Corporation, Billerica, MA, USA), which was centrifuged at $2000 \mathrm{~g}$ for $3 \mathrm{~h}$ at $37^{\circ} \mathrm{C}$. Samples were analyzed by LC-MS/MS as described above. The concentrations of MI-219 in the filtrate were determined by comparing with those of a standard curve containing known amounts of MI-219 dissolved in protein-free plasma (Macromolecules had been removed from the plasma by $10 \mathrm{kD}$ cut-off ultrafiltration). The unbound fraction was estimated from the ratio of MI-219 concentration in the filtrate to that in the original plasma samples. Parallel studies using protein-free plasma instead of plasma indicated that MI-219 was bound minimally to the ultrafiltration device.

To determine the protein binding of MI-219 in liver microsomes, liver microsomes were diluted with $0.1 \mathrm{M}$ phosphate buffer to $1 \mathrm{mg} / \mathrm{mL}$ and spiked with MI-219 to yield a final concentration of $1 \mu \mathrm{M}$. After incubation at $37^{\circ} \mathrm{C}$ for $1 \mathrm{~h}$, an aliquot was transferred to a $10 \mathrm{kD}$ cut-off ultrafiltration device, which was centrifuged at $2000 \mathrm{~g}$ for $3 \mathrm{~h}$ at $37^{\circ} \mathrm{C}$. The concentrations of MI-219 in the filtrate were determined by comparing with those of a standard curve containing known amounts of MI-219 dissolved in ultrafiltrated $1 \mathrm{mg} / \mathrm{mL}$ liver microsome solution. The unbound fraction was estimated from the ratio of MI-219 concentration in the filtrate to $1 \mu \mathrm{M}$. 
Blood-plasma partitioning (BP ratio)

$\mathrm{BP}$ ratios was measured using a previously published method (14). MI-219 was added to whole blood to obtain a final concentration of $5 \mu \mathrm{M}$ and incubated at $37^{\circ} \mathrm{C}$ for $30 \mathrm{~min}$. Plasma was separated from blood samples and concentration of MI-219 was determined by comparing with a standard curve prepared in blank plasma. The blood/plasma concentration ratio (BP) was determined by dividing $5 \mu \mathrm{M}$ by that found in plasma separated from blood samples.

The concentration of MI-219 in blood cells is assumed to be equal to its unbound concentration in plasma. The theoretical BP ratio was calculated using equation 1 (14).

$$
\mathrm{BP}=1+\mathrm{H} \times\left(\mathrm{f}_{\mathrm{u}}-1\right)
$$

where $\mathrm{fu}$ is the fraction of unbound in plasma, and $\mathrm{H}$ is the hematocrit (mouse, 0.45; rat, 0.46; dog, 0.42; monkey, 0.41; rabbit, 0.36; human, 0.44)(15).

Prediction of pharmacokinetics of MI-219 in human

Simple Allometric scaling (SA)

The CL $\left(\mathrm{L}^{*} \mathrm{~h}^{-1}\right)$ and Vss (L) values of MI-219 in animals and body weight $\mathrm{W}(\mathrm{kg})$ of animals after logarithmic conversion were fitted to logtransformed form of the following allometric equations (16) by linear regression:

$$
C L=a \times W^{b} \quad V d s=a^{\prime} \times W^{c}
$$

Where a and a' are the coefficients; b and c are the exponents of simple allometry. Human CLwas extrapolated using the fitted line and an assumed body weight of $70 \mathrm{~kg}$.

Allometric scaling after normalized by in-vitro metabolic data

Human and animal in vitro intrinsic $\mathrm{CL}\left(\mathrm{CL}_{\text {int,in vitro }}\right)$ was used to correct in vivo CL prior to allometric scaling. $\mathrm{CL}_{\text {int,in vitro }}$ of MI-219 was derived from in vitro elimination rate constant in various liver microsomes.

$$
C L_{\text {int }, \text { invitro }}=\frac{0.693}{T_{1 / 2} \times C_{\text {protein }}}=\frac{K_{e}}{C_{\text {protein }}}
$$

$C L_{\text {animal }}^{\prime}=C L_{\text {animal }} \times \frac{\text {HumanC}_{\text {int, } \text { invitro }}}{\text { AnimalCL }_{\text {int, }, \text { invitro }}}=\frac{K_{e, \text { human }}}{K_{e, \text { animal }}}$

[4]

where $\mathrm{K}_{\mathrm{e}}$ and $\mathrm{C}_{\text {protein }}(1 \mathrm{mg} / \mathrm{mL})$ were the rate constant of drug elimination in liver microsomes and the concentration of liver microsomes respectively.

Two-term power equation (TTPE)

CL was scaled allometrically by using an empirical equation which contains two power terms.

$$
C L=a \times W^{\alpha} \times B r W^{\beta}
$$

where BrW is the brain weight.

Multi-exponential Allometric scaling (ME)

To avoid the uncertainty around the selection of correction factor used with SA, multi-exponential allometric scaling equation (17) was used to predict CL of MI-219 in human.

$$
C L=a \times W^{b}+\frac{1-\frac{3}{2} b}{1-\frac{1}{2} b} \times a \times W^{0.9}
$$

where $\mathrm{a}$ and $\mathrm{b}$ are the coefficient and exponent of $\mathrm{SA}$; W is human body weight $(70 \mathrm{~kg})$.

\section{Single species scaling}

The following single species scaling equations (18) were employed to predict CL of MI-219 in human:

$$
\begin{gathered}
C L_{\text {human }} / \mathrm{kg}=0.41 \times C L_{\text {dog }} / \mathrm{kg} \\
C L_{\text {human }} / \mathrm{kg}=0.152 \times C L_{\text {rat }} / \mathrm{kg} \\
C L_{\text {human }} / \mathrm{kg}=0.407 \times C L_{\text {monkey }} / \mathrm{kg}
\end{gathered}
$$

\section{$f_{u}$ corrected intercept method (FCIM)}

$$
C L=33.35 \mathrm{ml} / \min \times\left(\frac{a}{R f_{u}}\right)^{0.77}
$$

where $\mathrm{Rf}_{\mathrm{u}}$ is the ratio of unbound fraction in plasma between rats and humans and $\mathrm{a}$ is the coefficient of SA. 
Physiologically based in vitro-in vivo extrapolation (IVIVE)

CL of MI-219 in humans was predicted using the physiologically based in vitro-in vivo extrapolation (IVIVE). To assess the prediction performance of this method, CL of MI-219 in mice and rats were also predicted using IVIVE. The in vitro intrinsic CL of MI-219 in mouse, rat and human liver microsomes were scaled up to whole-organ in vivo intrinsic CL by using the following scaling factors: microsomal protein yield per gram of liver $(\mathrm{mg} / \mathrm{g})$ : mouse, rat and monkey, 45; and human, 32; and liver weight ( $\mathrm{g} / \mathrm{kg}$ body weight): mouse, 87.5 ; rat, 40; monkey, 30; and human, $26(14,15)$. The in vivo intrinsic $C L$ was corrected with the fractions unbound in plasma and liver microsomes. Then, the corrected in vivo intrinsic CL was used to calculate hepatic CL in mice, rats and humans by using wellstirred model and parallel-tube model (19). The values of liver blood flow $\left(\mathrm{L}^{*} \mathrm{~h}^{-1} * \mathrm{~kg}^{-1}\right)$ were as follows: mouse 5.4; rat, 4.2; monkey, 2.7; and human, $1.24(14,15)$. The calculated hepatic CL was then converted to plasma CL by multiplying BP ratio of MI-219 (MI-219 was assumed to be cleared exclusively by hepatic metabolism).

$C L_{\text {int,in vivo }}=\frac{K_{e}}{C_{\text {protein }}} \times \frac{32 \mathrm{mg} \text { protein }}{1 \mathrm{~g} \text { liver weight }} \times \frac{26 \mathrm{~g} \text { liver weight }}{\mathrm{kg} \text { body weight }}$

$$
C L_{\text {int, in vivo }}^{\prime}=\frac{f u_{p}}{f u_{m}} \times C L_{\mathrm{int}, \text { in vivo }}
$$

Well-stirred model

$$
C L_{H}=\frac{Q_{H} \times C L^{\prime}{ }_{\text {int, in vivo }}}{Q_{H}+C L^{\prime}{ }_{\text {int, } \text { in vivo }}}
$$

Parallel-tube model

$$
\begin{gathered}
C L_{H}=Q_{H} \times\left(1-e^{-\frac{C L_{\text {int, invivo }}^{\prime}}{Q_{H}}}\right) \\
C L_{p}=C L_{H} \times B P
\end{gathered}
$$

Allometric scaling of unbound volume of distribution of tissues $\left(V_{T} / f u_{T}\right)$

The correlation between human and rat unbound volume of distribution of tissues $\left(\mathrm{V}_{\mathrm{T}} / \mathrm{fu}_{\mathrm{T}}\right)$ was utilized to estimate human $\mathrm{Vd}_{\mathrm{ss}}$. (20)

$$
\begin{gathered}
\left(\frac{V_{T}}{f u_{T}}\right)_{\text {rat }}=\frac{V d_{s s, \text { rat }}-V_{b, \text { rat }} \times B P_{\text {rat }}}{f u_{p, \text { rat }}} \\
\left(\frac{V_{T}}{f u_{T}}\right)_{\text {human }}=\left(\frac{V_{T}}{f u_{T}}\right)_{\text {rat }}^{0.951} \quad[14] \\
V d_{S S, \text { human }}=f u_{p, \text { human }} \times\left(\frac{V_{T}}{f u_{T}}\right)_{\text {human }}+V_{b, \text { human }} \times B P_{\text {human }}
\end{gathered}
$$

where $V_{T}$ was volume of tissue and $\mathrm{fu}_{\mathrm{T}}$ was the drug unbound fraction in tissue; $\mathrm{V}_{\mathrm{b}}$ was the blood volume (human, $0.0743 \mathrm{~L} / \mathrm{kg}$; rat, $0.054 \mathrm{~L} / \mathrm{kg}$ ).

\section{Oie-Tozer equation}

Oie-Tozer equation was used to calculate human $\mathrm{Vd}_{\mathrm{ss}}$ from unbound fraction in plasma $(\mathrm{fu}, \mathrm{p})$ and tissue $(\mathrm{fu}, \mathrm{T})$, the plasma volume $\left(\mathrm{V}_{\mathrm{p}}: 0.0313\right.$, $0.0448,0.0515$ and $0.0436 \mathrm{~L} / \mathrm{kg}$ for rat, monkey, dog and human), the extracellular fluid volume $\left(\mathrm{V}_{\mathrm{e}}\right.$ : $0.265,0.208,0.216$ and $0.151 \mathrm{~L} / \mathrm{kg}$ for rat, monkey, dog and human), the ratio of extravascular to intravascular proteins $\left(\mathrm{R}_{\mathrm{e} / \mathrm{i}}: 1.4\right.$ for all the species), the tissue volume minus extracellular space $\left(\mathrm{V}_{\mathrm{r}}\right.$ : $0.364,0.485,0.450$ and $0.38 \mathrm{~L} / \mathrm{kg})(21)$. The unbound fractions in tissue $\mathrm{fu}_{\mathrm{T}}$ of rats, monkey and dogs were calculated from corresponding $\mathrm{Vd}_{\mathrm{ss}}$ and the average value of $\mathrm{fu}_{\mathrm{T}}$ was used to calculate human $\mathrm{Vd}_{\mathrm{ss}}$.

$$
f u_{T}, \text { animal }=\frac{V_{r} \times f u_{p}}{V d_{S S}-V_{p}-f u \times V_{e}-\left(1-f u_{p}\right) \times R_{e / i} \times V_{p}}
$$

$$
V d_{\text {SShuman }}=V_{p}+f u_{p, \text { human }} \times V_{e}+\left(1-f u_{p, \text { humah }}\right) \times R_{e / i} \times V_{p}+V_{r} \times\left(\frac{f u_{p, \text { human }}}{\left.f u_{T, \text { averag }}\right)}\right)
$$

\section{Dedrick plots}

The plasma concentration-time profile of MI-219 in humans (assume an i.v administration of $5 \mathrm{mg} / \mathrm{kg}$ of MI-219) was simulated by using two Dedrick plot methods (based on Kallynochrons and 
Apolysichrons)(8, 11, 22). The equations of the Dedrick plot methods were listed as below.

Kallynochrons (elementary Dedrick plot):

$$
\begin{aligned}
& \text { Time }_{H}=\text { Time }_{A} \times\left(\frac{W_{H}}{W_{A}}\right)^{1-b} \\
& {\text { Conc } \cdot_{H}}=\text { Conc }_{\cdot} \times \frac{\text { Dose }_{H}}{\text { Dose }_{A}} \times \frac{W_{A}}{W_{H}}
\end{aligned}
$$

Apolysichrons:

$$
\begin{gathered}
\text { Time }_{H}=\text { Time }_{A} \times\left(\frac{W_{H}}{W_{A}}\right)^{c-b} \\
\text { Conc }_{\cdot}=\text { Conc }_{\cdot} \times \frac{\text { Dose }_{H}}{\text { Dose }_{A}} \times\left(\frac{W_{A}}{W_{H}}\right)^{c}
\end{gathered}
$$

Where $\mathrm{W}(\mathrm{kg})$ was the average body weight of animal or humans; Dose was in milligram. b and c were the exponents of simple allometry of CL and $\mathrm{Vd}_{\mathrm{ss}}$. The CLs in different animal species were multiplied by their respective MLP and plotted as a function of the body weight on a log-log scale to generate exponent $d$. The superimposition of the transformed animal concentration-time curves was expected. A two-compartment model (WinNonlin, version 5.2.1) was used to fit the superimposed curves. The goodness of fit was evaluated by correlation of observed and predicted values $\left(\mathrm{r}^{2}\right)$ and Akaike Information Criteria (AIC)(10).

\section{Wajima's method}

The plasma concentration-time profile of MI-219 in humans was predicted by normalizing concentration-time profiles in animals with MRT $\left(\mathrm{MRT}=\mathrm{Vd}_{\mathrm{ss}} / \mathrm{CL}\right)$ and $\mathrm{C}_{\mathrm{ss}}\left(\mathrm{C}_{\mathrm{ss}}=\right.$ Dose $\left./ \mathrm{Vd}_{\mathrm{ss}}\right)(9)$. The superimposition of the normalized animal concentration-time curves was expected. The normalized animal concentrations and times were transformed into human concentrations and times by multiplying the predicted human $\mathrm{C}_{\mathrm{ss}}$ and MRT. Similar to Dedrick plot analysis, a twocompartment model (WinNonlin, version 5.2.1) was used to fit the predicted human plasma concentration-time profile of MI-219.

Interspecies scaling of pharmacokinetics of MI-219 using NONMEM

Interspecies allometric scaling of pharmacokinetics of MI-219 was performed using NONMEM (Version VII; ICON Development Solutions,
Ellicott City, MD, USA) to predict the human PK profile(23). In the first step, a two-compartment pharmacokinetic (PK) model with linear elimination from the central compartment was developed to describe the concentration-time profile of MI-219 in different animal species. The effect of body weight on CL and volume of distribution was modeled as $\mathrm{P}_{\mathrm{i}}=\mathrm{P}_{\mathrm{TV}} * \mathrm{WT}_{\mathrm{i}}^{b}$, where $\mathrm{P}_{\mathrm{i}}$ and $\mathrm{WT}_{\mathrm{i}}$ are the PK parameter of interest and the body weight of the $i^{\text {th }}$ animal species, and $\mathrm{P}_{\mathrm{TV}}$ is the typical value of the PK parameter in an animal with $1 \mathrm{~kg}$ body weight. In the second stage, the model estimates, $\mathrm{P}_{\mathrm{TV}}$ and exponent $b$, were used to predict the $\mathrm{Vd}_{\mathrm{ss}}$ in human, and human PK profile was simulated with the derived model.

\section{RESULTS}

\section{Metabolic stability assay}

The percentages of MI-219 remaining in mouse, rat, dog, monkey and human liver microsomes (1 $\mathrm{mg} / \mathrm{mL}$ ) after 5, 10, 15, 30, 45 and $60 \mathrm{~min}$ incubation are presented in Figure 1. In all species tested, more than $50 \%$ of MI-219 was metabolized after incubation for $1 \mathrm{~h}$, suggesting MI-219 was extensively metabolized by CYP enzymes. The elimination rate constants and half-lives of MI-219 in mouse, rat, monkey, dog and human liver microsomes were shown in Table 1.

Plasma and liver microsome protein binding and blood-plasma partitioning (BP ratio)

As shown in Table 2, the unbound fraction of MI219 in mouse, rat, monkey, dog and human plasma at a concentration of $5 \mu \mathrm{M}$ ranged from $1.39 \%$ to $4.45 \%$. The unbound fractions of MI-219 $(1 \mu \mathrm{M})$ in $1 \mathrm{mg} / \mathrm{mL}$ of mouse, rat, monkey and human liver microsomes are $2.03 \%, 2.44 \%, 4.40 \%$ and $6.16 \%$ respectively. The BP ratios of MI-219 in mice, rats and humans are experimentally measured and range from 0.572 to 0.597 , which agree with the BP ratio values calculated from corresponding $\mathrm{fu}_{\mathrm{p}}$.

Pharmacokinetics of MI-219 in rat, mouse, dog and monkey

Figure 2 is a semi-log plot of MI-219 plasma concentration versus time for mouse, rat, dog, and monkey following intravenous administration. The concentrations of MI-219 in mouse plasma at $24 \mathrm{~h}$ are lower than the limit of quantification $(2 \mathrm{ng} / \mathrm{mL})$ of the LC-MS/MS assay. The pharmacokinetic parameters of MI-219 in the four species are summarized in Table 3. 


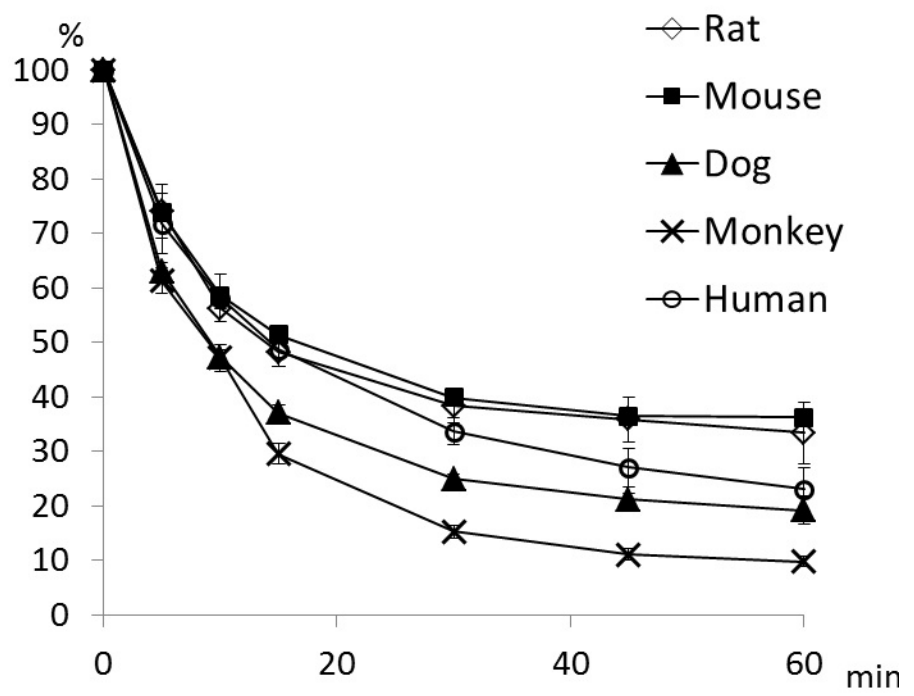

Figure 1. Metabolic stability of MI-219 in animal and human liver microsomes $(\mathrm{n}=3)$

\begin{tabular}{|c|c|c|c|c|c|}
\hline Species & Mouse & Rat & Monkey & Dog & Human \\
\hline Elimination rate constant $\left(\mathrm{min}^{-1}\right)$ & 0.04449 & 0.04935 & 0.07842 & 0.06535 & 0.04747 \\
\hline Half-life (min) & 15.6 & 14.0 & 8.8 & 10.6 & 14.6 \\
\hline
\end{tabular}

\begin{tabular}{ccccc}
\hline \multicolumn{5}{c}{ Table 2. Unbound fraction of MI-219 in plasma and liver microsomes and blood-plasma partition } \\
\hline Species & $\begin{array}{c}\text { Unbound fraction } \\
\text { in plasma(fu }\end{array}$ & $\begin{array}{c}\text { Unbound fraction in } \\
\text { liver microsome(fu }\end{array}$ & $\begin{array}{c}\text { Blood-Plasma } \\
\text { partition (calculated) }\end{array}$ & $\begin{array}{c}\text { Blood-Plasma partition } \\
\text { (measured) }\end{array}$ \\
\hline Mouse & $4.45 \% \pm 0.04 \%$ & $2.03 \% \pm 0.29 \%$ & 0.570 & $0.581 \pm 0.010$ \\
Rat & $3.87 \% \pm 0.79 \%$ & $2.44 \% \pm 0.73 \%$ & 0.558 & $0.597 \pm 0.008$ \\
Monkey & $1.96 \% \pm 0.65 \%$ & $4.40 \% \pm 0.94 \%$ & 0.598 & N.A. \\
Dog & $1.39 \% \pm 0.48 \%$ & $\mathrm{~N} . \mathrm{A}$. & 0.586 & N.A. \\
Human & $1.65 \% \pm 0.27 \%$ & $6.16 \% \pm 0.58 \%$ & 0.567 & $0.572 \pm 0.006$ \\
\hline
\end{tabular}

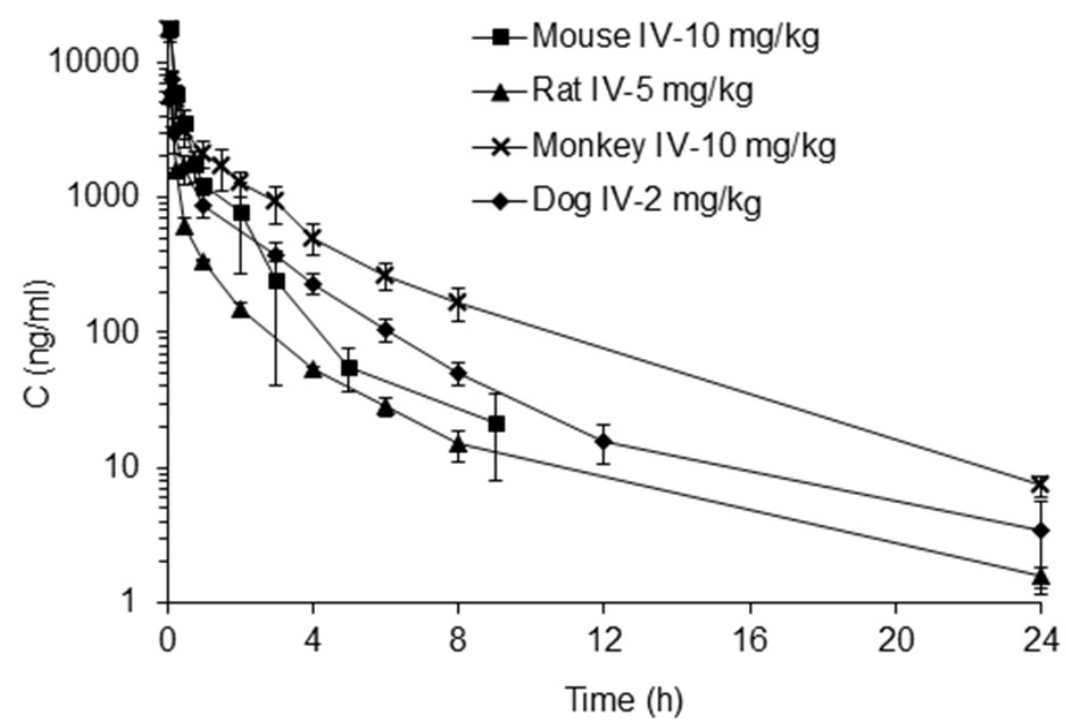

Figure 2. Mean plasma concentration-time following single intravenous administration of MI-219. Mice (three animals per time point), rats $(\mathrm{n}=3)$, dogs $(\mathrm{n}=3)$, and monkeys $(\mathrm{n}=6)$. * The concentrations of MI-219 in mouse plasma at $24 \mathrm{hr}$ postinjection were lower than $\mathrm{LOQ}$. 
MI-219 has high plasma CLs in mice and rats at 7.15 and $2.13 \mathrm{~L}^{*} \mathrm{~h}^{-1} * \mathrm{~kg}^{-1}$, respectively. The corresponding blood CLs in mice and rats are 12.31 and $3.57 \mathrm{~L}^{*} \mathrm{~h}^{-1} * \mathrm{~kg}^{-1}$, respectively (more than $80 \%$ of hepatic blood flow). Especially, the blood CL exceeds hepatic blood flow in mice. In monkeys, MI-219 had a moderate plasma CL of 0.85 $\mathrm{L}^{*} \mathrm{~h}^{-1} * \mathrm{~kg}^{-1}$ and blood CL of $1.42 \mathrm{~L}^{*} \mathrm{~h}^{-1} * \mathrm{~kg}^{-1}$ (approximately 53\% of hepatic blood flow) (15). In dogs, MI-219 had a moderate plasma CL of 0.36 $\mathrm{L}^{*} \mathrm{~h}^{-1} * \mathrm{~kg}^{-1}$ and blood CL of $0.61 \mathrm{~L}^{*} \mathrm{~h}^{-1} * \mathrm{~kg}^{-1}$ (approximately $34 \%$ of hepatic blood flow). The terminal half-life $\left(\mathrm{t}_{1 / 2}\right)$ ranged from $1.89 \mathrm{~h}$ in mice to $3.90 \mathrm{~h}$ in dogs. The volume of distribution at steady-state $\left(\mathrm{Vd}_{\mathrm{ss}}\right)$ ranged from $0.60 \mathrm{~L}^{*} \mathrm{~kg}^{-1}$ in dogs to $6.37 \mathrm{~L}^{*} \mathrm{~kg}^{-1}$ in mice.

\section{Prediction of CL of MI-219 in humans}

To validate various approaches for CL prediction, monkey CL was predicted from in vitro and/or in vivo data obtained from human liver microsomes, mice, rats and monkeys. As shown in Table 4, the predicted monkey CLs by simple allometric scaling (SA), allometric scaling normalized by microsomal data, TTPE, ME and IVIVE were 0.63, 0.73, 0.65, $0.91,0.82$ (IVIVE, well-stirred model) and 1.04
$\mathrm{L}^{*} \mathrm{~h}^{-1} * \mathrm{~kg}^{-1} \quad$ (IVIVE, parallel-tube model), respectively. ME and IVIVE provided more accurate predictions than the other approaches. Single species scaling and FCIM are not applicable to monkey CL prediction.

The predicted human CL by SA was 0.146 $\mathrm{L}^{*} \mathrm{~h}^{-1} * \mathrm{~kg}^{-1}$. The coefficient and exponent for SA of CL were 1.076 and 0.5301 , respectively (Figure $3 \mathrm{~A})$. According to Rule of Exponents (RoE), the CL $\left(0.146 \mathrm{~L}^{*} \mathrm{~h}^{-1} * \mathrm{~kg}^{-1}\right)$ is likely to be underestimated since the exponent is less than 0.55 (4). Corrections with maximum lifespan potential (MLP) or brain weight (BrW) would not apply. To eliminate the interspecies differences in hepatic metabolism, animal CL was corrected by multiplying the ratio of elimination rate constants in human and animal liver microsomes $\left(\mathrm{K}_{\mathrm{e}, \mathrm{human}} / \mathrm{K}_{\mathrm{e} \text {,animal }}\right)$. Allometric scaling of the corrected animal CL resulted in a lower predicted CL $\left(0.08 \mathrm{~L}^{*} \mathrm{~h}^{-1} * \mathrm{~kg}^{-1}\right)$ (Figure 3B).

Figure 4 shows the plot of $\mathrm{CL}$ against body weight (W) and brain weight (BrW) by using twoterm power equation (TTPE). TTPE showed a good correlation among $\mathrm{CL}, \mathrm{W}$ and $\mathrm{BrW}$ and the coefficient of determination $\left(\mathrm{r}^{2}\right)$ was 0.9988 . The predicted human CL was $0.184 \mathrm{~L}^{*} \mathrm{~h}^{-1} * \mathrm{~kg}^{-1}$.

Table 3. Pharmacokinetics (mean \pm standard deviation) of MI-219 in animals

\begin{tabular}{ccccccccc}
\hline Species & $\begin{array}{c}\text { Body } \\
\text { weight } \\
(\mathrm{kg})\end{array}$ & $\begin{array}{c}\text { Dose } \\
\left(\mathrm{mg}^{*} \mathrm{~kg}^{-1}\right)\end{array}$ & $\begin{array}{c}\mathrm{AUC}_{(0-\infty)} \\
\left(\mathrm{h}^{*} \mathrm{ng}^{*-1}\right)\end{array}$ & $\begin{array}{c}\mathrm{MRT}_{(0-\infty)} \\
(\mathrm{h})\end{array}$ & $\begin{array}{c}\mathrm{Vd}_{\mathrm{z}} \\
\left(\mathrm{L}^{*} \mathrm{~kg}^{-1}\right)\end{array}$ & $\begin{array}{c}\mathrm{T} / 1 / 2 \\
(\mathrm{~h})\end{array}$ & $\begin{array}{c}\mathrm{CL} \\
\left(\mathrm{L}^{*} \mathrm{~kg}{ }^{-1}\right)\end{array}$ & $\begin{array}{c}\mathrm{L}^{*} \mathrm{~h}^{-1} \mathrm{~kg}^{-} \\
\left.{ }^{1}\right)\end{array}$ \\
\hline Mouse & 0.018 & 10 & $7046 \pm 760$ & $0.9 \pm 0.04$ & $19.53 \pm 2.12$ & $1.89 \pm 0.04$ & $6.37 \pm 0.40$ & $7.15 \pm 0.76$ \\
Rat & 0.2 & 5 & $2349 \pm 30$ & $1.38 \pm 0.12$ & $6.76 \pm 1.14$ & $2.20 \pm 0.34$ & $2.95 \pm 0.31$ & $2.13 \pm 0.03$ \\
Monkey & 2.5 & 10 & $11884 \pm 1714$ & $2.41 \pm 0.28$ & $4.13 \pm 0.56$ & $3.35 \pm 0.09$ & $2.07 \pm 0.35$ & $0.85 \pm 0.12$ \\
Dog & 8 & 2 & $6236 \pm 2312$ & $1.63 \pm 0.36$ & $1.89 \pm 0.39$ & $3.90 \pm 0.78$ & $0.60 \pm 0.32$ & $0.36 \pm 0.14$ \\
\hline
\end{tabular}

\begin{tabular}{|c|c|c|}
\hline Methods & $\begin{array}{l}\text { Predicted monkey CL } \\
\left(\mathrm{L}^{*} \mathrm{~h}^{-1} * \mathrm{~kg}^{-1}\right)\end{array}$ & Predicted human CL $\left(\mathrm{L}^{*} \mathrm{~h}^{-1} * \mathrm{~kg}^{-1}\right)$ \\
\hline Simple allometry & 0.63 & 0.146 \\
\hline $\begin{array}{l}\text { Allometric scaling normalized by in vitro } \\
\text { microsomal data }\end{array}$ & 0.73 & 0.080 \\
\hline Two term power equation & 0.65 & 0.184 \\
\hline Multi-exponential allometric scaling & 0.91 & 0.342 \\
\hline Single species scaling & N.A. & $\begin{array}{c}0.324 \text { (rat), } 0.148(\mathrm{dog}), 0.346 \\
\text { (monkey) }\end{array}$ \\
\hline Physiologically based in vitro-in vivo & 0.82 (well-stirred model) & 0.237 (well-stirred model) \\
\hline scaling & 1.04 (parallel-tube model) & 0.282 (parallel-tube model) \\
\hline $\mathrm{f}_{\mathrm{u}}$ corrected intercept method & N.A. & 0.168 \\
\hline
\end{tabular}



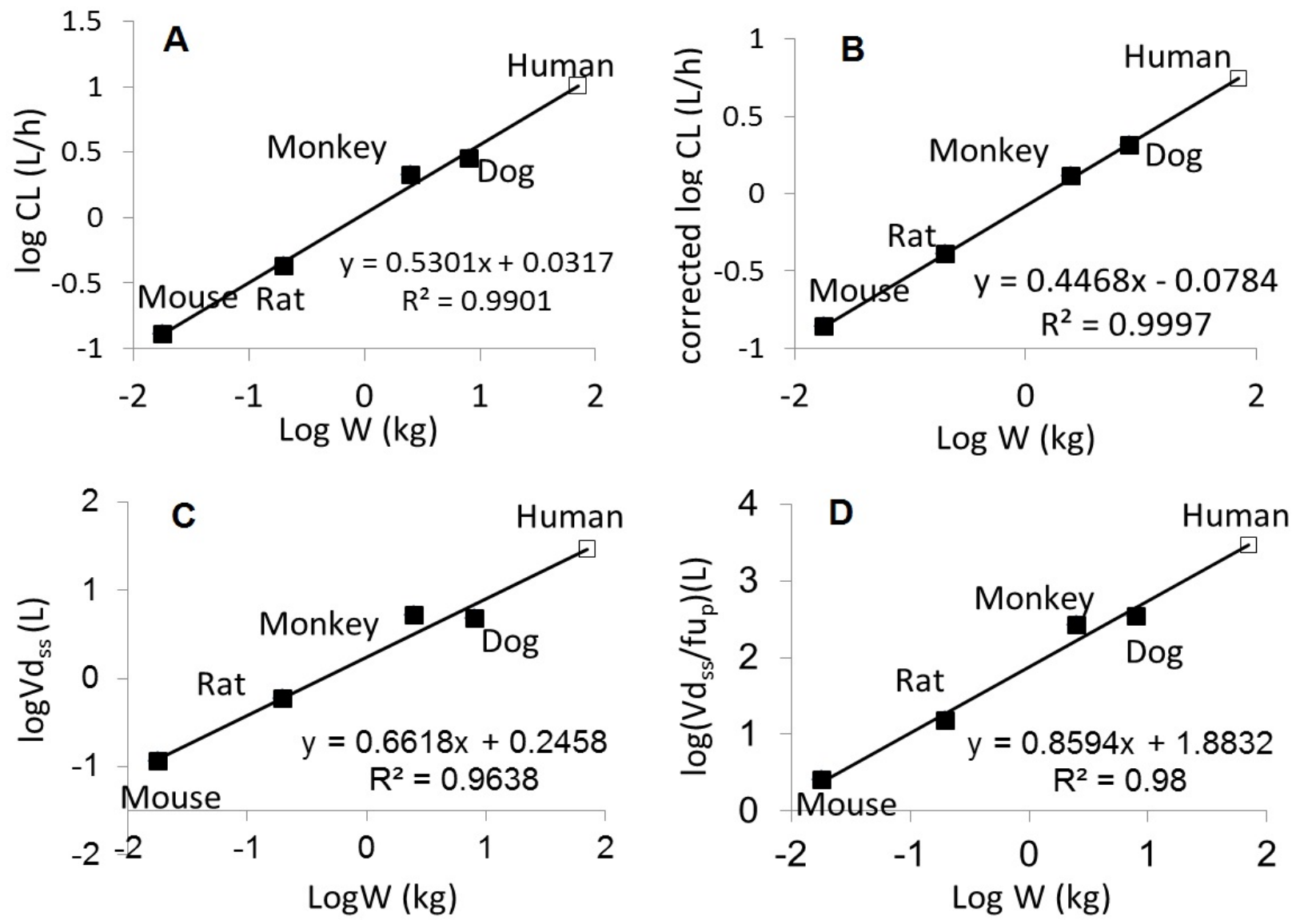

Figure 3. Allometric scaling of CL (A); CL corrected by microsomal data (B); $\mathrm{Vd}_{\mathrm{ss}}(\mathrm{C})$; unbound $\mathrm{Vd}_{\mathrm{ss}}(\mathrm{D})$.

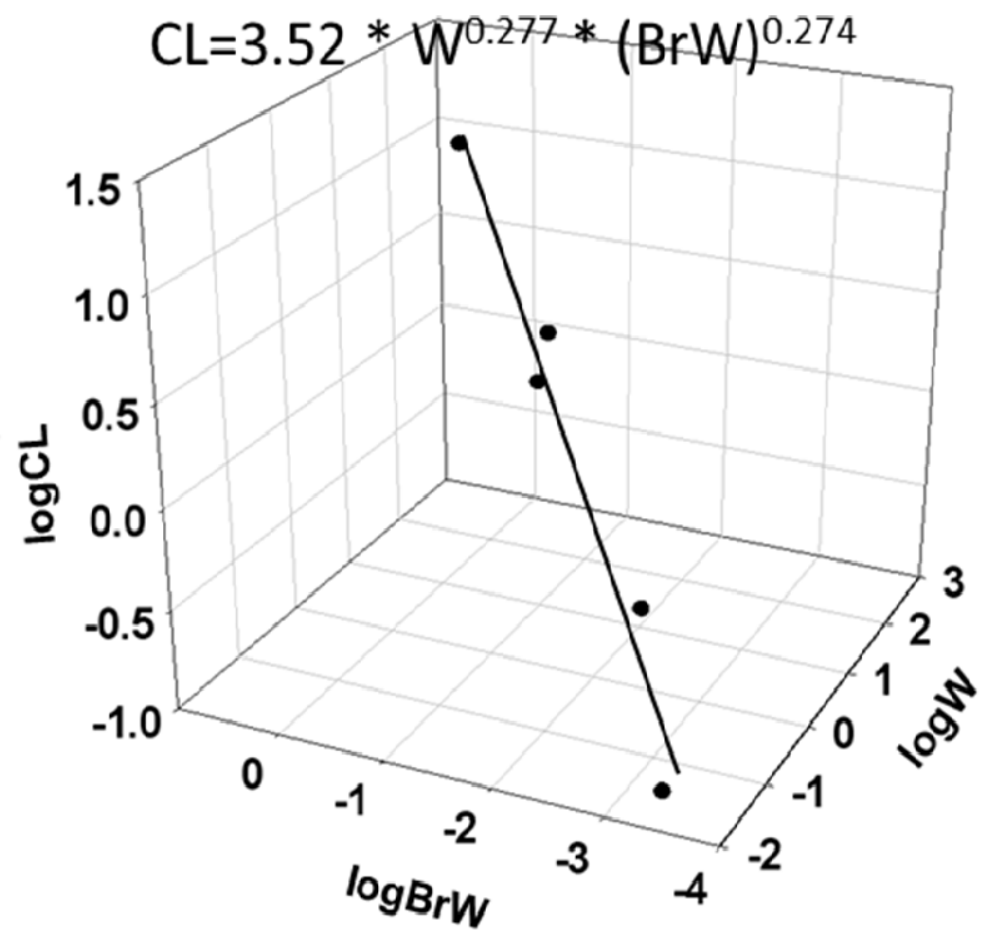

Figure 4. Human CL prediction using two-term power equation 
The coefficient (1.076) and exponent b (0.5301) obtained from SA of CL were applied to the multiexponential allometric scaling (ME) equation to estimate CL in human. The predicted human CL was $0.342 \mathrm{~L}^{*} \mathrm{~h}^{-1} * \mathrm{~kg}^{-1}$.

To simplify SA, single-species scaling methods proposed by Tang et. al. (18) were also applied to the prediction of CL of MI-219 in humans. A big variation was observed when the $\mathrm{CL}$ in humans was derived from rats $\left(0.324 \mathrm{~L}^{*} \mathrm{~h}^{-1} * \mathrm{~kg}^{-1}\right)$, dogs $(0.148$ $\left.\mathrm{L}^{*} \mathrm{~h}^{-1} * \mathrm{~kg}^{-1}\right)$, and monkeys $\left(0.346 \mathrm{~L}^{*} \mathrm{~h}^{-1} * \mathrm{~kg}^{-1}\right)$.

Considering the extremely high plasma protein binding of MI-219, the $f_{u}$ corrected intercept method (FCIM) was utilized to estimate CL of MI219 in humans. The ratio of $\mathrm{fu}_{\mathrm{p}}$ in rats and human $(0.0387 / 0.0165=2.345)$ and coefficient of simple allometry (0.0317) were applied to FCIM equation. The resulted CL in humans was $0.168 \mathrm{~L}^{*} \mathrm{~h}^{-1} * \mathrm{~kg}^{-1}$.

CL of MI-219 was scaled from in vitro intrinsic CL determined in human liver microsome incubation using physiologically based in vitro-in vivo extrapolation method. The elimination rate constant of MI-219 in $1 \mathrm{mg} / \mathrm{mL}$ human liver microsome was $0.04747 \mathrm{~min}^{-1}$. $\mathrm{fu}_{\mathrm{m}}$ in human liver microsome and $\mathrm{BP}$ ratio in human blood were determined as $6.16 \%$ and 0.572 . The predicted CL value in human was 0.237 or $0.282 \mathrm{~L}^{*} \mathrm{~h}^{-1} * \mathrm{~kg}^{-1}$ when well-stirred model or parallel-tube model was employed. To assess the prediction performance of IVIVE, the CL of MI-219 in mice and rats were also scaled from in vitro intrinsic CL in mouse and rat liver microsomes.

The CL in rats was estimated to be 1.675 $\mathrm{L}^{*} \mathrm{~h}^{-1} * \mathrm{~kg}^{-1} \quad$ (well-stirred model) and 2.172 $\mathrm{L}^{*} \mathrm{~h}^{-1} * \mathrm{~kg}^{-1}$ (parallel-tube model). The later one agreed well with the observed value (2.13 $\left.\mathrm{L}^{*} \mathrm{~h}^{-1} * \mathrm{~kg}^{-1}\right)$. The predicted CL values in mice by both well-stirred model $\left(2.66 \mathrm{~L}^{*} \mathrm{~h}^{-1} * \mathrm{~kg}^{-1}\right)$ and parallel-tube model $\left(3.23 \mathrm{~L}^{*} \mathrm{~h}^{-1} * \mathrm{~kg}^{-1}\right)$ were lower than the observed value $\left(7.15 \mathrm{~L}^{*} \mathrm{~h}^{-1} * \mathrm{~kg}^{-1}\right)$, indicating that other elimination mechanisms such as extrahepatic metabolism contributed to the total CL in mice. Human CLs of MI-219 predicted by various approaches were summarized in Table 4.

\section{Prediction of $V d_{s s}$ of MI-219 in humans}

To validate various approaches for $\mathrm{Vd}_{\mathrm{ss}}$ prediction, monkey $\mathrm{Vd}_{\mathrm{ss}}$ was predicted from mouse, rat and $\operatorname{dog} \mathrm{Vd}_{\mathrm{ss}}$. The monkey $\mathrm{Vd}_{\mathrm{ss}}$ values predicted by allometric scaling, allometric scaling of undound $\mathrm{Vd}_{\mathrm{ss}}$, and Oie-Tozer method were 1.29, 1.02 and $1.43 \mathrm{~L}^{*} \mathrm{~kg}^{-1}$ respectively. When dog data was removed from the data set, the predictions of monkey $\mathrm{Vd}_{\mathrm{ss}}$ by allometric scaling, allometric scaling of undound $\mathrm{Vd}_{\mathrm{ss}}$, and Oie-Tozer method were $1.32,0.77$ and $2.05 \mathrm{~L}^{*} \mathrm{~kg}^{-1}$, respectively. OieTozer equation provided the best predictions of monkey $\mathrm{Vd}_{\mathrm{ss}}$. Interspecies scaling of unbound volume of distribution of tissues $\left(\mathrm{V}_{\mathrm{T}} / \mathrm{fu}_{\mathrm{T}}\right)$ method is not applicable to monkey $\mathrm{Vd}_{\mathrm{ss}}$ prediction.

Estimates of $\mathrm{Vd}_{\mathrm{ss}}$ (L) from mouse, rat, dog and monkey pharmacokinetic studies were plotted against body weight $(\mathrm{kg})$ to predict human $\mathrm{Vd}_{\mathrm{ss}}$. Human $\mathrm{Vd}_{\mathrm{ss}}$ predicted by SA was $0.418 \mathrm{~L}^{*} \mathrm{~kg}^{-1}$ (Figure 3C). As a comparison, human $\mathrm{Vd}_{\mathrm{ss}}$ extrapolated from unbound $\mathrm{Vd}_{\mathrm{ss}}\left(\mathrm{Vd}_{\mathrm{ss}} / \mathrm{fu}_{\mathrm{p}}\right)$ of four animal species was $0.694 \mathrm{~L}^{*} \mathrm{~kg}^{-1}$ (Figure 3D). When human $\mathrm{Vd}_{\mathrm{ss}}$ was extrapolated from mouse, rat, and monkey data, the predicted values by SA and allometric scaling of unbound $\mathrm{Vd}_{\mathrm{ss}}$ were 0.90 and $1.22 \mathrm{~L}^{*} \mathrm{~kg}^{-1}$, respectively.

Interspecies scaling of $\mathrm{V}_{\mathrm{T}} / \mathrm{fu}_{\mathrm{T}}$ method was used to estimate $\mathrm{Vd}_{\mathrm{ss}}$ of MI-219 in human. $\mathrm{V}_{\mathrm{T}} / \mathrm{fu}_{\mathrm{T}}$ in rats was derived from rat $\mathrm{Vd}_{\mathrm{ss}}$ as $75.4 \mathrm{~L}^{*} \mathrm{~kg}^{-1} . \mathrm{V}_{\mathrm{T}} / \mathrm{fu}_{\mathrm{T}}$ in human was $61.0 \mathrm{~L}^{*} \mathrm{~kg}^{-1}$, resulting in a $\mathrm{Vd}_{\mathrm{ss}}$ in human of $1.05 \mathrm{~L}^{*} \mathrm{~kg}^{-1}$. Physiologically based OieTozer equation was used to predict $\mathrm{Vd}_{\mathrm{ss}}$ in human. $\mathrm{fu}_{\mathrm{T}}$ of rats $(0.00491), \operatorname{dogs}(0.0131)$ and monkeys $(0.00475)$ were derived from corresponding $\mathrm{Vd}_{\mathrm{ss}}$. The average $\mathrm{fu}_{\mathrm{T}}$ of the three species was used to calculate $\mathrm{Vd}_{\mathrm{ss}}$ of MI-219 in human, which was determined as $0.93 \mathrm{~L}^{*} \mathrm{~kg}^{-1}$. When the average $\mathrm{fu}_{\mathrm{T}}$ of rats and monkeys was used as human $\mathrm{fu}_{\mathrm{T}}$, the predicted human $\mathrm{Vd}_{\mathrm{ss}}$ was $1.40 \mathrm{~L}^{*} \mathrm{~kg}^{-1}$.

\section{Dedrick plot analysis}

Two Dedrick plot methods were applied for the prediction of the plasma concentration-time profile and half-life $\left(t_{1 / 2}\right)$ of MI-219 in human. The plasma concentration-time curves obtained from mice, rats, monkeys and dogs were normalized according to the pharmacokinetic times of kallynochrons (elementary Dedrick plot) and apolysichrons (complex Dedrick plot). As shown in Figure 5, reasonable superimposition was observed among the curves transformed from rat, monkey and dog plasma concentration-time profiles. However, the curve transformed from mouse plasma concentration-time profile was not superimposable to other curves. Hence, only the curves derived from rats, monkeys and dogs were used to predict human pharmacokinetics. A two-compartment model was employed to fit the superimposed curves using WinNonlin. The predicted human pharmacokinetic parameters (alpha, beta, A, B, CL, $\mathrm{Vd}_{\mathrm{ss}}, \mathrm{MRT}$, and $\mathrm{t}_{1 / 2}$ ), coefficients of correlation and 
AIC were shown in Table 5. The kallynochron transformation resulted in CL $\left(0.148 \mathrm{~L}^{*} \mathrm{~h}^{-1} * \mathrm{~kg}^{-1}\right)$ and $\mathrm{Vd}_{\mathrm{ss}}\left(0.406 \mathrm{~L}^{*} \mathrm{~kg}^{-1}\right)$ comparable with that derived from SA. The human CL predicted by apolysichron time transformation $(0.164$ $\mathrm{L}^{*} \mathrm{~h}^{-1} * \mathrm{~kg}^{-1}$ ) was more comparable with those obtained by TTPE and FCIM methods. The $t_{1 / 2}$ values predicted by kallynochrons and apolysichrons transformations were $3.08 \mathrm{~h}$ and 2.53 $\mathrm{h}$ respectively.

\section{Wajima's method}

To estimate $t_{1 / 2}$, the concentration-time profiles in mice, rats, dogs and monkeys were normalized by MRT and $\mathrm{C}_{\mathrm{ss}}$. Reasonable superimposition was observed among the normalized curves from rats, monkeys and dogs (Figure 6A). The normalized mouse curve was not superimposable to other curves. The normalized concentrations and times from rats, monkeys and dogs were transformed into human concentrations and times by multiplying the predicted human $\mathrm{C}_{\mathrm{ss}}$ and MRT. Since allometric scaling tends to underpredict $\mathrm{CL}$ and $\mathrm{Vd}_{\mathrm{ss}}$, the average CL predicted from TTPE $(0.184$ $\left.\mathrm{L}^{*} \mathrm{~h}^{-1} * \mathrm{~kg}^{-1}\right), \operatorname{ME}\left(0.342 \mathrm{~L}^{*} \mathrm{~h}^{-1} * \mathrm{~kg}^{-1}\right)$, FCIM $(0.168$ $\left.\mathrm{L}^{*} \mathrm{~h}^{-1} * \mathrm{~kg}^{-1}\right)$ and IVIVE methods $(0.237$ and 0.282 $\left.\mathrm{L}^{*} \mathrm{~h}^{-1} * \mathrm{~kg}^{-1}\right)$ and the $\mathrm{Vd}_{\mathrm{ss}}$ predicted from Oie-Tozer equation $\left(0.93 \mathrm{~L}^{*} \mathrm{~kg}^{-1}\right)$ were utilized to generate MRT $(3.85 \mathrm{~h})$ and $\mathrm{C}_{\mathrm{ss}}\left(5.38 \mathrm{mg}^{*} \mathrm{~L}^{-1}\right)$ in human. The transformed human concentrations and times were plotted (Figure 6B) and fitted with a twocompartment model using WinNonlin. The predicted human pharmacokinetic parameters (alpha, beta, A, B, CL, $\mathrm{Vd}_{\mathrm{ss}}, \mathrm{MRT}$, and $\mathrm{t}_{1 / 2}$ ) were listed in Table 5. The $\mathrm{r}^{2}(0.979)$ and AIC (543) values suggested a good curve-fitting.

\section{Interspecies scaling using NONMEM}

Finally, we coupled allometric scaling with NONMEM approach, which can model multiple PK parameters simultaneously and predict human plasma concentration-time profile. Pharmacokinetic parameters of rats, dogs and monkeys were estimated from measured plasma concentrations using individual or combined NONMEM models (Table S1). The estimated animal parameters were scaled to human parameters by the derived NONMEM interspecies scaling model. Human PK profile after i.v. administration was simulated (Figure 7) and human PK parameters were predicted (Table 5). The developed model was validated in all the animal species. The observed animal PK profile falls in the 5th and 95th quantile of model simulations, in all animal species. Figure $S 2$ showed the validation in dogs.
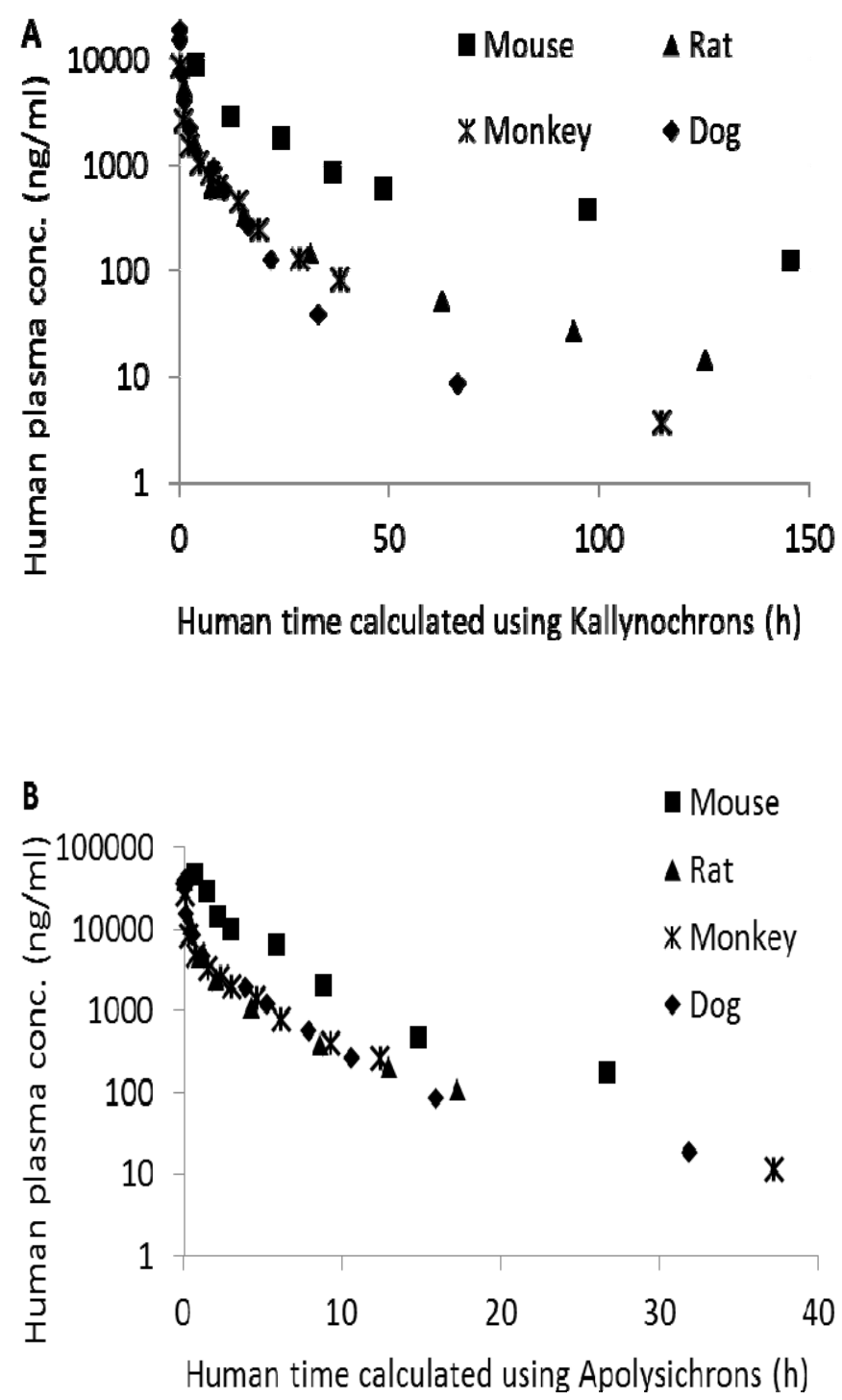

Figure 5. Predicted plasma concentration-time profiles in humans following a single i.v. injection of MI-219 (5 $\mathrm{mg} \mathrm{kg}^{-1}$ ) based on Kallynochrons (A) and Apolysichrons (B) time transformation. 
Table 5. Predicted pharmacokinetic parameters of MI-219 in humans by Detrick plot, Wajima's method and NONMEM modeling

\begin{tabular}{ccccc}
\hline Parameters & $\begin{array}{c}\text { Kallynochr } \\
\text { ons }\end{array}$ & Apolysichrons & Wajima's method & NONMEM \\
\hline alpha & 5.671 & 4.521 & 4.644 & 2.839 \\
beta & 0.225 & 0.274 & 0.253 & 0.161 \\
A & 76308 & 56043 & 32457 & 21714 \\
B & 4554 & 4957 & 3017 & 3109 \\
CL $\left(\mathrm{L}^{*} \mathrm{~h}^{-1} \mathrm{~kg}^{-1}\right)$ & 0.148 & 0.164 & 0.265 & 0.186 \\
$\mathrm{Vd}_{\mathrm{ss}}\left(\mathrm{L} \mathrm{h}^{-1}\right)$ & 0.406 & 0.370 & 0.679 & 0.843 \\
$\mathrm{MRT}^{(\mathrm{h})}$ & 2.74 & 2.25 & 2.57 & 4.53 \\
$\mathrm{~T}_{1 / 2}$ & 3.08 & 2.53 & 2.73 & 4.30 \\
$\mathrm{R}^{2}$ & 0.958 & 0.952 & 0.979 & N.A. \\
$\mathrm{AIC}$ & 556 & 619 & 543 & N.A. \\
\hline
\end{tabular}

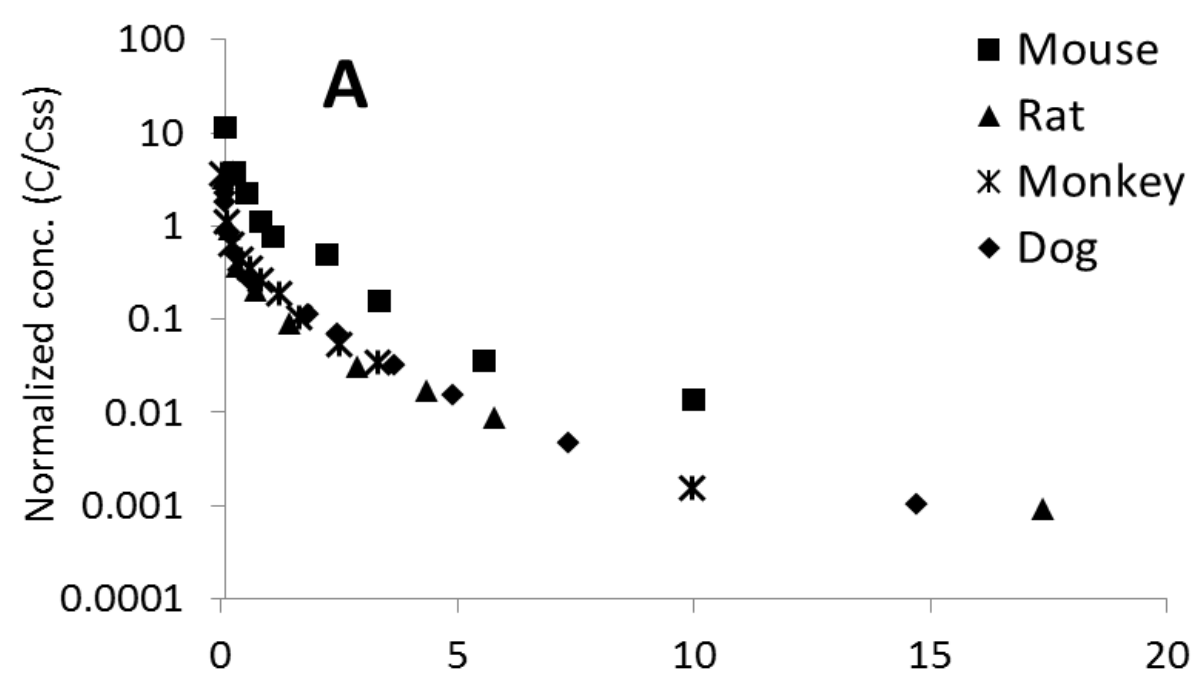

Normalized time (t/MRT)

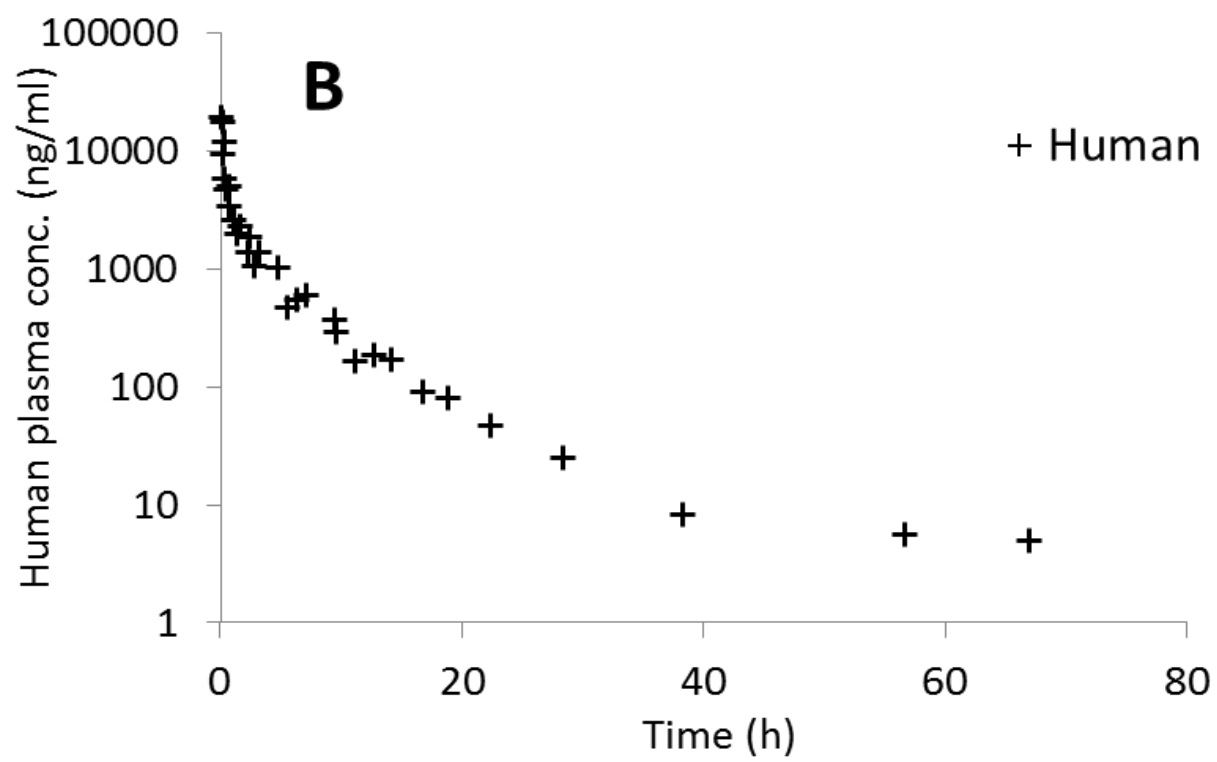

Figure 6. Superimposition of normalized concentration-time profiles of MI-219 in animals using Css and MRT (Wajima's method) (A) and predicted human concentration-time profile following a single i.v. injection of MI-219 (5 mg* $\left.\mathrm{kg}^{-1}\right)(\mathrm{B})$ 


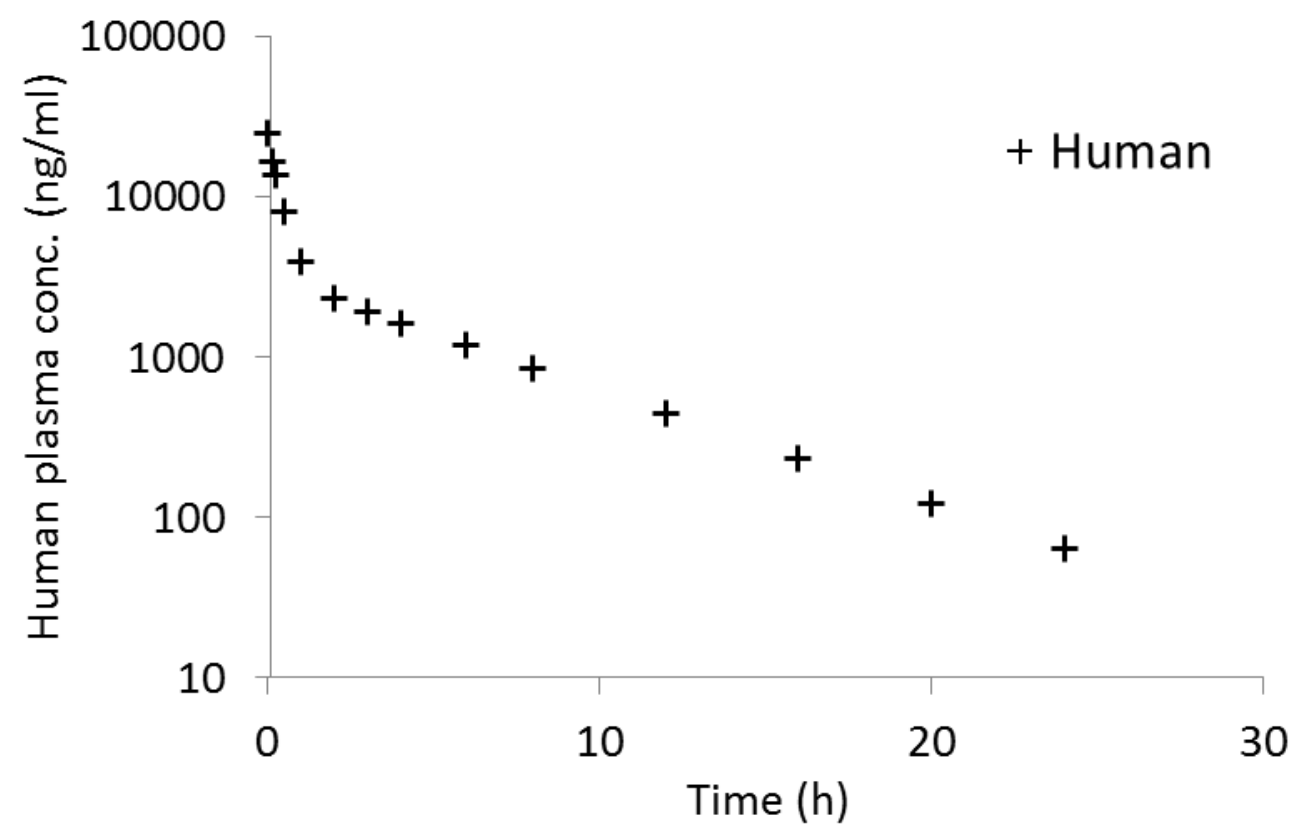

Figure 7. Human concentration-time profile following a single i.v. injection of MI-219 $\left(5 \mathrm{mg}^{*} \mathrm{~kg}^{-1}\right)$ predicted by allometric scaling-based NONMEM modeling.

\section{DISCUSSION}

Effective inhibition of p53 wild-type tumors in preclinical models makes MI-219 an attractive candidate for anti-cancer drug development (1). Accurate prediction of human pharmacokinetics of MI-219 is critical for the assessment of its potential to succeed as a drug. Numerous approaches based on in vitro and in vivo preclinical data for human pharmacokinetics are available but there is no universal approach that will work for every compound. Although allometric scaling techniques are simple and most widely used in industry, the use of allometric scaling should be cautious due to its empirical nature. In current study, we intend to utilize and evaluate various approaches including both empirical and physiologically based approaches for predicting pharmacokinetic parameters of MI-219 in humans.

The results from animal pharmacokinetic studies show that MI-219 has moderate to high plasma $C L$ in all species $\left(E_{H}>0.3\right)$. Especially, the blood CL in mice exceeds the hepatic blood flow, implying the existence of non-hepatic CL of MI219 in mice. Since renal CL does not contribute significantly to the systemic CL of MI-219, the high CL of MI-219 is likely due to both hepatic and extrahepatic metabolism. Rapid metabolic turnover of MI-219 in mouse, rat, monkey, dog and human liver microsome incubation suggests extensive hepatic metabolism. High volume of distribution in mice, rats and monkeys suggests extensive distribution of MI-219 in peripheral tissues.

Considering the moderate-to-high hepatic extraction ratios of MI-219 in animals, it is not surprising that simple allometric scaling (SA) of CL showed a good correlation between CL and body weights since CL of compounds with high hepatic extraction ratios is limited by liver blood flow, which is well correlated with body weights across species (24). However, it has been suggested that a high $\mathrm{r}^{2}$ value does not warrant an accurate $\mathrm{CL}$ prediction(25). Incorporation of elimination rate constants determined in live microsome incubations generated a lower CL prediction compared with SA. As declared in the Rule of Exponent (RoE), human CL of MI-219 is likely underestimated by SA since the exponent is less than 0.55 and the application of correction factors such as MLP and BrW will not improve the prediction (4). Consistently, CL of MI219 in monkey was underpredicted by allometric scaling with or without correction factors.

The CL values of MI-219 estimated using single-species scaling exhibited great variation when scaled from different species. The interspecies difference limits its application in human CL prediction. Human CLs predicted by two other empirical approaches, TTPE and FCIM, are higher than that obtained from SA. In TTPE, CL is allometrically correlated with both body weight and 
brain weight, which probably performs better than SA for some compounds. Unfortunately, TTPE provided an underestimation of monkey CL. FCIM was developed to correct vertical allometry. Compared with SA, FCIM minimizes the prediction errors caused by the interspecies difference in plasma protein binding between rats and human(26). However, FCIM ignores the difference in metabolic activities between rats and humans and it cannot be validated with animal data.

The assumption of multi-exponential allometric scaling (ME) is that CL is correlated with both body weight and volumes of elimination organs such as liver and kidneys (17). ME gave a good prediction of monkey CL, suggesting that this method can correct the underprediction caused by SA. The human CL $\left(0.342 \mathrm{~L}^{*} \mathrm{~h}^{-1} * \mathrm{~kg}^{-1}\right)$ obtained from ME is 2-fold higher than that predicted by SA $(0.146$ $\left.\mathrm{L}^{*} \mathrm{~h}^{-1} * \mathrm{~kg}^{-1}\right)$. ME utilizes both the exponent of SA (0.5301) and a fix exponent 0.9 to correlate human CL and body weight. The first exponent reflects the relationship between CL and body weight while the fix exponent reflects the relationship between hepatic CL and liver weight across species.

Interspecies differences in protein binding and metabolic enzymes are likely to result in inaccurate predictions of human CL by SA. Physiologically based IVIVE method is designed to minimize the errors caused by these interspecies differences by incorporating in vitro intrinsic $\mathrm{CL}$, unbound fraction in plasma $\left(\mathrm{fu}_{\mathrm{p}}\right)$ and unbound fraction in liver microsomes $\left(\mathrm{fu}_{\mathrm{m}}\right)$ into the equations $(27)$. To verify the predictability of IVIVE, CLs of MI-219 in mouse, rat and monkey were predicted using this approach. Although an underprediction of CL in mouse was observed, the predicted CLs in rat and monkey agreed well with the observed CLs. The underprediction of CL in mouse is probably due to extrahepatic clearance. Hence, to accurately predict human CL, more in vitro investigation is required to detect the possible extrahepatic clearance of MI-219 in humans.

The observed $\operatorname{dog}$ CL and predicted human CL are lower than that of the other species. The low CLs in dogs and humans are probably due to the interspecies differences in protein binding, hepatic physiological parameters, and/or biliary excretion. High protein binding in dog and human plasma results in low $\mathrm{Vd}_{\mathrm{ss}}$ and decreased hepatic metabolism. Compared with rats and mice, humans and dogs have lower hepatic blood flow, lower microsomal proteins per gram of liver, and lower liver weight per $\mathrm{kg}$ of body weight. In addition, biliary excretion and enterohepatic circulation can decrease the CL in dogs and human, which might explain the difference in CL between $\operatorname{dog}$ and monkey.

Similar to CL prediction, underestimation of monkey $\mathrm{Vd}_{\mathrm{ss}}$ by $\mathrm{SA}$ and allometric scaling of unbound $\mathrm{Vd}_{\mathrm{ss}}$ were observed. Oie-Tozer method provided better prediction of monkey $\mathrm{Vd}_{\mathrm{ss}}$ than allometric scaling (28). The underestimation of monkey $\mathrm{Vd}_{\mathrm{ss}}$ is mainly caused by the low dog $\mathrm{Vd}_{\mathrm{ss}}$. The removal of dog $\mathrm{Vd}_{\mathrm{ss}}$ from the data set resulted in a good prediction of monkey $\mathrm{Vd}_{\mathrm{ss}}$ by Oie-Tozer method. Consistent with monkey $\mathrm{Vd}_{\mathrm{ss}}$ prediction, Oie-Tozer method provided a higher prediction of human $\mathrm{Vd}_{\mathrm{ss}}\left(0.93 \mathrm{~L}^{*} \mathrm{~kg}^{-1}\right)$ than allometric scaling methods. When dog $\mathrm{Vd}_{\mathrm{ss}}$ was removed, the predicted human $\mathrm{Vd}_{\mathrm{ss}}$ was $1.40 \mathrm{~L}^{*} \mathrm{~kg}^{-1}$. Both the two predictions are comparable to the human $\mathrm{Vd}_{\mathrm{ss}}$ predicted by allometric scaling of $\mathrm{V}_{\mathrm{T}} / \mathrm{fu}_{\mathrm{T}}$ from rat data $\left(1.05 \mathrm{~L}^{*} \mathrm{~kg}^{-1}\right)$. One advantage of Oie-Tozer method and allometric scaling of $\mathrm{V}_{\mathrm{T}} / \mathrm{fu}_{\mathrm{T}}$ method is that they can minimize the errors caused by interspecies differences in plasma protein binding and tissue binding by incorporating unbound fractions in plasma and tissues into the equations. In contrast, allometric scaling of unbound Vdss ignores tissue binding and $\mathrm{SA}$ ignores both tissue binding and plasma protein binding.

Detrick plot method was used to predict the plasma concentration-time profile of MI-219 in human. After kallynochron and apolysichron transformation, the data from rats, monkeys and dogs were superimposable. Essentially, Detrick plot method originated from the allometric scaling approach and its prediction performance depends on the allometric relationships of the pharmacokinetic parameters cross species. Therefore, the CL and $\mathrm{Vd}_{\mathrm{ss}}$ estimated by kallynochron and apolysichron methods are comparable to those obtained from SA. The advantage of Detrick plots is that it can be used to estimate half-life and AUC which are important for the design of human doses.

To avoid the possible underestimation of both $\mathrm{CL}$ and $\mathrm{Vd}_{\mathrm{ss}}$ from allometric scaling and Detrick plots, Wajima's normalization method was also employed to predict the concentration-time profile of MI-219 in humans. CL and $\mathrm{Vd}_{\mathrm{ss}}$ derived from physiologically-based methods (IVIVE, FCIM, and Oie-Tozer equation) instead of simple allometric scaling were used to estimate human concentrationtime profile, which fitted the two-compartment model better than the data transformed from Detrick plots. 
In summary, the pharmacokinetics of MI-219 was studied in mice, rats, monkeys and dogs after i.v. injection. The pharmacokinetic parameters of MI-219 in humans were predicted using various empirical and physiologically based methods. The plasma concentration-time profile in humans was predicted using Detrick plot method and Wajima's $\mathrm{C}_{\mathrm{ss}}$-MRT method. The validation using monkey in vivo PK parameters showed that ME and IVIVE approaches provided better CL predictions than the other approaches. Oie-Tozer method was superior to the other approaches for $\mathrm{Vd}_{\mathrm{ss}}$ prediction. Monkey $\mathrm{CL}$ and $\mathrm{Vd}_{\mathrm{ss}}$ were underpredicted by allometric scaling methods. When applied to human PK prediction, ME and IVIVE predicted comparable human CLs (0.237, 0.282 and $\left.0.342 \mathrm{~L}^{*} \mathrm{~h}^{-1} * \mathrm{~kg}^{-1}\right)$. Oie-Tozer method and allometric scaling of $\mathrm{V}_{\mathrm{T}} / \mathrm{fu}_{\mathrm{T}}$ method also provided similar predictions of human $\mathrm{Vd}_{\mathrm{ss}} \quad\left(0.93\right.$ or 1.40 and $\left.1.05 \quad \mathrm{~L}^{*} \mathrm{~kg}^{-1}\right)$. Superimposition of rat, monkey and dog data and good curve fitting were observed after apolysichron time transformation and normalization with MRT and $\mathrm{Vd}_{\mathrm{ss}}$. The validation using monkey in vivo data and a narrow range of the predicted human PK parameters provides us a confidence in the human PK predictions of MI-219.

\section{ACKNOLEDGEMENT}

This work was partially supported by the National Institutes of Health (RO1 CA120023 and R21 CA143474); University of Michigan Cancer Center Research Grant (Munn); and University of Michigan Cancer Center Core Grant to DS.

\section{REFERENCES}

1. Becquemont L, Le Bot MA, Riche C, FunckBrentano C, Jaillon P, Beaune P. Use of heterologously expressed human cytochrome P450 $1 \mathrm{~A} 2$ to predict tacrine-fluvoxamine drug interaction in man. Pharmacogenetics1998 Apr;8(2):101-8.

2. Bachmann K, Pardoe D, White D. Scaling basic toxicokinetic parameters from rat to man. Environ Health Perspect1996 Apr;104(4):400-7.

3. McIlwrath AJ, Brunton VG, Brown R. Cell-cycle arrests and p53 accumulation induced by geldanamycin in human ovarian tumour cells. Cancer Chemotherapy and Pharmacology1996 Mar;37(5):423-8.

4. Mahmood I. Application of allometric principles for the prediction of pharmacokinetics in human and veterinary drug development. Adv Drug Deliv Rev2007 Sep 30;59(11):1177-92.
5. Hosea NA, Collard WT, Cole S, Maurer TS, Fang $\mathrm{RX}$, Jones $\mathrm{H}$, et al. Prediction of human pharmacokinetics from preclinical information: comparative accuracy of quantitative prediction approaches. J Clin Pharmacol2009 May;49(5):51333.

6. Fagerholm U. Prediction of human pharmacokinetics--evaluation of methods for prediction of volume of distribution. J Pharm Pharmacol2007 Sep;59(9):1181-90.

7. Oie S, Tozer TN. Effect of altered plasma protein binding on apparent volume of distribution. J Pharm Sci1979 Sep;68(9):1203-5.

8. Shin BS, Kim DH, Cho CY, Park SK, Chung SG, Cho EH, et al. Pharmacokinetic scaling of SJ-8029, a novel anticancer agent possessing microtubule and topoisomerase inhibiting activities, by speciesinvariant time methods. Biopharm Drug Dispos2003 Jul;24(5):191-7.

9. Wajima T, Yano Y, Fukumura K, Oguma T. Prediction of human pharmacokinetic profile in animal scale up based on normalizing time course profiles. J Pharm Sci2004 Jul;93(7):1890-900.

10. Cho CY, Shin BS, Jung JH, Kim DH, Lee KC, Han $\mathrm{SY}$, et al. Pharmacokinetic scaling of bisphenol A by species-invariant time methods. Xenobiotica2002 Oct;32(10):925-34.

11. Mahmood I, Yuan R. A comparative study of allometric scaling with plasma concentrations predicted by species-invariant time methods. Biopharm Drug Dispos1999 Apr;20(3):137-44.

12. Shim HJ, Kim YC, Lee JH, Kwon JW, Kim WB, Kim YG, et al. Interspecies pharmacokinetic scaling of DA-8159, a new erectogenic, in mice, rats, rabbits and dogs, and prediction of human pharmacokinetics. Biopharm Drug Dispos2005 Oct;26(7):269-77.

13. Goetz MP, Toft D, Reid J, Ames M, Stensgard B, Safgren S, et al. Phase I trial of 17-allylamino-17demethoxygeldanamycin in patients with advanced cancer. J Clin Oncol2005 Feb 20;23(6):1078-87.

14. Lee HK, Moon JK, Chang CH, Choi H, Park HW, Park BS, et al. Stereoselective metabolism of endosulfan by human liver microsomes and human cytochrome P450 isoforms. Drug Metabolism and Disposition2006 Jul;34(7):1090-5.

15. Satoh $\mathrm{K}$. The high non-enzymatic conjugation rates of some glutathione S-transferase (GST) substrates at high glutathione concentrations. Carcinogenesis1995 Apr;16(4):869-74.

16. Boxenbaum H. Interspecies pharmacokinetic scaling and the evolutionary-comparative paradigm. Drug Metab Rev1984;15(5-6):1071-121.

17. Goteti K, Brassil PJ, Good SS, Garner CE. Estimation of human drug clearance using multiexponential techniques. J Clin Pharmacol2008 Oct;48(10):1226-36. 
18. Tang H, Hussain A, Leal M, Mayersohn M, Fluhler E. Interspecies prediction of human drug clearance based on scaling data from one or two animal species. Drug Metab Dispos2007 Oct;35(10):188693.

19. Chiba M, Ishii Y, Sugiyama Y. Prediction of hepatic clearance in human from in vitro data for successful drug development. AAPS J2009 Jun;11(2):262-76.

20. Sawada $Y$, Hanano $M$, Sugiyama $Y$, Iga $T$. Prediction of the disposition of nine weakly acidic and six weakly basic drugs in humans from pharmacokinetic parameters in rats. J Pharmacokinet Biopharm1985 Oct;13(5):477-92.

21. Obach RS, Baxter JG, Liston TE, Silber BM, Jones $\mathrm{BC}$, MacIntyre $\mathrm{F}$, et al. The prediction of human pharmacokinetic parameters from preclinical and in vitro metabolism data. J Pharmacol Exp Ther1997 Oct;283(1):46-58.

22. Shibayama T, Matsushita Y, Kurihara A, Hirota T, Ikeda T. Prediction of pharmacokinetics of CS-023 (RO4908463), a novel parenteral carbapenem antibiotic, in humans using animal data. Xenobiotica2007 Jan;37(1):91-102.

23. Zheng $\mathrm{N}$, Yu J, Zou P, Feng R, Interspecies Pharmacokinetic Scaling of Mycophenolic Acid Using Nonlinear Mixed Effects. American Association Pharmaceutical Scientists Annual Meeting; 2010; New Orleans, LA.
24. Lave T, Coassolo P, Reigner B. Prediction of hepatic metabolic clearance based on interspecies allometric scaling techniques and in vitro-in vivo correlations. Clin Pharmacokinet1999 Mar;36(3):211-31.

25. Tang H, Mayersohn M. Utility of the coefficient of determination ( $\mathrm{r} 2$ ) in assessing the accuracy of interspecies allometric predictions: illumination or illusion? Drug Metab Dispos2007 Dec;35(12):213942.

26. Tang H, Mayersohn M. A novel model for prediction of human drug clearance by allometric scaling. Drug Metab Dispos2005 Sep;33(9):1297303.

27. Zou P, Yu Y, Zheng N, Yang Y, Paholak HJ, Yu LX, Sun D. Applications of human pharmacokinetic prediction in First-in-Human Does estimation. The AAPS Journal 2012 in press, DOI: 10.1208/s12248012-9332-y

28. Zou P, Yu Y, Zheng N, Yang Y, Yu LX, Sun D. Prediction of Volume of Distribution at Steady-State in Humans: Comparison of Different Approaches. Expert Opin Drug Metab Toxicol. 2012 in press DOI: $10.1517 / 17425255.2012 .682569$. 